H. KAUR, S. KUMARI, R.C. GUPTA

Department of Botany, Punjabi University, Patiala, 147002 India E-mail: harpreetsidhu75@gmail.com

\section{CYTOMORPHOLOGICAL STUDIES IN SOME MEMBERS OF TRIBE PANICEAE (POACEAE) FROM DISTRICT KANGRA OF HIMACHAL PRADESH (WESTERN HIMALAYAS)}

The present paper deals with cytological studies on the population basis of 21 species belonging to 9 genera of tribe Paniceae of family Poaceae from cytologically unexplored area of Western Himalayas i.e. district Kangra of Himachal Pradesh for the assessment of genetic diversity of grass flora. On world-wide basis, the chromosome counts have been made for the first time for three species such as Brachiaria remota $(n=16)$, Digitaria granularis $(n=36)$ and Isachne albens $(n=$ $=5$ ). Similarly, on India basis, altogether new records are made for two species such as Echinochloa cruspavonis $(n=27)$ and Paspalum distichum $(2 n=50)$. A comparison of the different euploid cytotypes studied at present for Digitaria adscendens, D. setigera and Oplismenus compositus revealed significant variations in their morphology, depicting increase in some of the characters of polyploid cytotypes. The course of meiosis has been observed to be normal in all the studied populations with high pollen fertility except for two species such as Paspalum dilatatum and P. distichum marked with abnormal meiosis and reduced pollen fertility.

(C) H. KAUR, S. KUMARI, R.C. GUPTA, 2013
Introduction. The members of tribe Paniceae are annual or perennial herbs, rarely woody, with inflorescence comprising of more or less similar spikelets. It is one of the economically most important tribes of the family since many of its species are good forage (Brachiaria ramosa, Digitaria adscendens, Paspalidium flavidum) and grain crops (Echinochloa crus-gallii, Urochloa panicoides). Certain species (Echinochloa crus-gallii) are known to possess folk remedy for treating carbuncles, haemorrhages, sores, spleen trouble, cancer and wounds [1]. Taxonomically, the Paniceae is one of the largest and most complex tribes in the family Poaceae, consisting of about 82 genera and 1460 species [2] and 30 genera and 193 species recorded from Indian sub-continent [3]. Cytologically, a significant contribution to the tribe Paniceae has been made by different researchers such as [4] from Taiwan and [5] from China along with contribution of some Indian cytologists as [6] from South India, [7] from Central \& Eastern Himalayas. Significant work in this direction for the Western Himalayan grasses has been previously done but from other distant places like Kashmir (Jammu \& Kashmir) [7-10]; Mussoorie (Uttrakhand) [11]; Nainital (Uttrakhand) [12]; Shimla (Himachal Pradesh) $[10,11,13]$ and lower Shivalik hills (Punjab \& Haryana) $[13,14]$. However, from district Kangra (Himachal Pradesh) selected by us, not even a single cytological report is available for the grasses. It is noted from literature that different species of the tribe are known to exhibit well marked inter- and intraspecific chromosomal diversity both at diploid and /or polyploid levels. To analyze the cytomorphological diversity at population level, the meiotic studies have been carried out in different grass species on the population basis from newly marked area at present being cytologically explored for the first time.

Materials and methods. In all the cytotypes, variable characters were studied for each cytotype to have proper insight of morphological variation. For stomatal studies, mature leaves were treated with $10 \%$ aqueous solution of Potassium hydroxide $(\mathrm{KOH})$ at room temperature for $10-15 \mathrm{~min}$ and then epidermal peels were observed. Stomatal size was measured using occulomicrometer.

For meiotic studies, young spikes were collected on population basis from various localities of district Kangra of Himachal Pradesh. Meiotic studies were carried out through standard smearing technique from young spikes fixed in Car-

ISSN 0564-3783. Цитология и генетика. 2013. № 2 
noy's fixative. For the analysis of meiotic abnormalities, large numbers of PMCs were observed for each type of anomaly. Pollen fertility was estimated by mounting mature pollen grains in glycerol-acetocarmine (1:1) mixture. Well-filled pollen grains with stained nuclei were taken as apparently fertile while shrivelled and unstained pollen grains were counted as sterile. Pollen grain size was measured using occulomicrometer. Photomicrographs of pollen mother cells were made from freshly prepared slides using Nikon 80i eclipse Digital Imaging System. Voucher specimens are deposited in the Herbarium, Department of Botany, Punjabi University, Patiala (PUN).

Results. At present, detailed meiotic studies have been carried out on 73 populations of 21 species belonging to 9 genera of tribe Paniceae. The information about specific locality, altitude, accession number, meiotic chromosome number, figure number, ploidy level and course of meiosis is given in Table 1. To assess the status of presently worked out cytotypes, the results are checked in light of total previous chromosomal reports available from [15-17], various Journals and Proceeding volumes. Further, for each species out of the heavy lists of chromosome number data only a few selected references are picked up just to stress on those reports which show some significant changes. Morphological comparison has been made for 3 species as shown in Table 2.

Alloteropsis cimicina (L.) Stapf. The presently worked out populations are found to be common near waste places in the altitudinal range of $500-700 \mathrm{~m}$ in district Kangra. The species is characterized by absence of silky base of sheath; spikelets usually green and upper lemma abruptly and shortly aristate. The genus is based on $x=9$. Presently, this grass species with $n=18$ is found to be tetraploid in conformity with the earlier report of $2 n=36$ given by various researchers from India and outside India. The other chromosome report for the species, $2 n=30$ likely to be aneuploid was reported by [18] from Bihar (India).

Brachiaria ramosa (L.) Stapf. The species is commonly known as browntop millet. As a leafy grass, it has good fodder value. The presently worked out populations are found at an altitudinal range of $400-800 \mathrm{~m}$ in the damp and shady places. The species is easily recognized by spikelets gla- brous and pubescent, pedicel and rachis with long colorless hairs. On the basis of cumulative worldwide literature, the genus is based on $x=6,7,8$, 9 with 7 and 9 being dominating base numbers. This species is reported to exhibit $2 n=14,28$, $32,36,42,46,72$ chromosome numbers speaking of existence of intraspecific polyploid cytotypes $(2 x, 4 x, 6 x$ and $8 x)$. However, in this species the gametic number is noted to be $n=16$ and based on $x=8$, it is at tetraploid level in conformity with earlier such reports available from North-Western and eastern parts of India only [7, 10, 14, 19].

B. remota (Retz.) Haines. The populations worked out at present are found to be common in shady places along roadsides in district Kangra within altitudinal range of $500-800 \mathrm{~m}$. The species is characterized by culm weak, decumbent, upto $60 \mathrm{~cm}$ tall, leaves linear and spikelets oblong obtuse. In the presently worked out species, new cytotype with $n=16$ based on $x=8$ at tetraploid level has been recorded on world-wide basis for the first time. With the same base number, earlier report of octoploid cytotype with $2 n=64$ by [20] from outside India and another cytotype based on $x=9$ at tetraploid level with $2 n=36$ by [21] from India are also available in literature.

Digitaria adscendens (H.B.K.) Henr. It is one of the largest genera of the tribe Paniceae and this species is very common all over the India. The presently worked out populations are found to be common along open fields between altitudes of 500-1000 m in district Kangra. The species is characterized by spikelets elliptic-lanceolate, $2.5-3 \mathrm{~mm}$ long and without spreading hairs. The genus is based on $x=7,8,9$, and 10 but 9 being highly common base number. For the studied species, two cytotypes occurring as hexaploid with $n=27$ and octoploid with $n=36$, respectively, are reported at present from four different localities each. The species in India is already known to have similar cytotype with $2 n=54$ to be quite common in Punjab plains and south India and from many parts of the world outside India. The cytotype with $2 n=72$ was also previously reported mainly from different parts of north India along with single report of [22] from Costa Rican. The species also exhibits other cytotypes with chromosome numbers as $2 n=18$ as diploid [23] from Taiwan and polyploids as $2 n=36$, 60, 68, 70 mainly from India. Morphologically, 
Table 1

Information about area, locality, altitude, accession number, meiotic chromosome number reports, ploidy level and meiotic course of different species of tribe Paniceae (Poaceae) from district Kangra of Himachal Pradesh (Western Himalayas)

\begin{tabular}{|c|c|c|c|c|}
\hline Taxa & Locality, Altitude (m) & $\begin{array}{c}\text { Accession numbers } \\
\text { (PUN) }\end{array}$ & $\begin{array}{c}\text { Meiotic chromosome } \\
\text { number }(n) \\
\text { (Figure number) }\end{array}$ & $\begin{array}{l}\text { Ploidy level/Meiotic } \\
\text { course }\end{array}$ \\
\hline \multirow{3}{*}{$\begin{array}{l}\text { Alloteropsis cimicina } \\
\text { (L.) Stapf }\end{array}$} & Dehra, 650 & 55270 & 18 (Fig. 1) & $4 x / \mathrm{N} *$ \\
\hline & Suliali, 500 & 55271 & 18 & $4 x / \mathrm{N}$ \\
\hline & Jwala Ji, 600 & 55731 & 18 & $4 x / \mathrm{N}$ \\
\hline Brachiaria ramosa (L.) & Bhanala, 800 & 55375 & 16 (Fig. 2) & $4 x / \mathrm{N}$ \\
\hline \multirow[t]{2}{*}{ Stapf } & Suliali, 500 & 55376 & 16 & $4 x / \mathrm{N}$ \\
\hline & Nagrota Surian, 527 & 55380 & 16 & $4 x / \mathrm{N}$ \\
\hline \multicolumn{5}{|l|}{ Haines } \\
\hline Digitaria adscendens & Dehra, 650 & 53519 & 27 (Fig. 4) & $6 x / \mathrm{N}$ \\
\hline \multirow[t]{7}{*}{ (H.B.K.) Henr. } & Samloti, 600 & 55710 & 27 & $6 x / \mathrm{N}$ \\
\hline & Suliali, 500 & 55702 & 27 & $6 x / \mathrm{N}$ \\
\hline & Mataur, 650 & 55711 & 27 & $6 x / \mathrm{N}$ \\
\hline & Nagrota Surian, 527 & 52615 & 36 (Fig. 5) & $8 x / \mathrm{N}$ \\
\hline & Banuri, 1350 & 55707 & 36 & $8 x / \mathrm{N}$ \\
\hline & Chhota Bhangal, 2000 & 55700 & 36 & $8 x / \mathrm{N}$ \\
\hline & Bara Gran, 3500 & 55704 & 36 & $8 x / \mathrm{N}$ \\
\hline D. granularis (Trin.) & Plachek, 2688 & 55701 & 36 (Fig. 6) & $8 x / \mathrm{N}$ \\
\hline \multirow[t]{4}{*}{ Henr. } & Jwala Ji, 600 & 55708 & 36 & $8 x / \mathrm{N}$ \\
\hline & Majhera, 1550 & 55713 & 36 & $8 x / \mathrm{N}$ \\
\hline & Paprola, 1400 & 55714 & 36 & $8 x / \mathrm{N}$ \\
\hline & Samloti, 600 & 55715 & 36 & $8 x / \mathrm{N}$ \\
\hline \multirow[t]{2}{*}{ D. longiflora (Retz.) Pers. } & Dehra, 650 & 52628 & 9 (Fig. 7) & $2 x / \mathrm{N}$ \\
\hline & Bhagsunaag, 1650 & 52643 & 9 & $2 x / \mathrm{N}$ \\
\hline D. setigera Roth ex & Nagrota Surian, 527 & 53583 & 27 (Fig. 8) & $6 x / \mathrm{N}$ \\
\hline \multirow{8}{*}{ Roem. \& Schult. } & Sakri, 530 & 53584 & 27 & $6 x / \mathrm{N}$ \\
\hline & Ranital, 550 & 55709 & 27 & $6 x / \mathrm{N}$ \\
\hline & Dehra, 650 & 53587 & 27 & $6 x / \mathrm{N}$ \\
\hline & Bhanala, 800 & 55703 & 27 & $6 x / \mathrm{N}$ \\
\hline & Swad, 2800 & 53539 & 36 (Fig. 9) & $8 x / \mathrm{N}$ \\
\hline & Chhota Bhangal, 2000 & 53555 & 36 & $8 x / \mathrm{N}$ \\
\hline & Bhagsunaag, 1650 & 53586 & 36 & $8 x / \mathrm{N}$ \\
\hline & Loharari, 2500 & 52629 & 36 & $8 x / \mathrm{N}$ \\
\hline D. stricta Roth ex & Bhanala, 800 & 55705 & 36 (Fig. 10) & $8 x / \mathrm{N}$ \\
\hline Roem. et Schult. & Panchrukhi, 1300 & 55712 & 36 & $8 x / \mathrm{N}$ \\
\hline \multirow[t]{3}{*}{ D. violascens Link } & Dharamsala, 1600 & 53537 & 18 (Fig. 11) & $4 x / \mathrm{N}$ \\
\hline & Bhagsunaag, 1650 & 53538 & 18 & $4 x / \mathrm{N}$ \\
\hline & Sakri, 530 & 53574 & 18 & $4 x / \mathrm{N}$ \\
\hline \multirow{5}{*}{$\begin{array}{l}\text { Echinochloa colo- } \\
\text { num (L.) Link. }\end{array}$} & Suliali, 500 & 55273 & 27 (Fig. 12) & $6 x / \mathrm{N}$ \\
\hline & Bhanala, 800 & 55274 & 27 & $6 x / \mathrm{N}$ \\
\hline & Dyot, 2800 & 55275 & 27 & $6 x / \mathrm{N}$ \\
\hline & Dehra, 650 & 55328 & 27 & $6 x / \mathrm{N}$ \\
\hline & Mataur, 650 & 55733 & 27 & $6 x / \mathrm{N}$ \\
\hline E. crus-gallii (L.) P. & Bhanala, 800 & 55282 & 27 (Fig. 13) & $6 x / \mathrm{N}$ \\
\hline \multirow[t]{4}{*}{ Beauv. } & Ranehar, 850 & 55335 & 27 & $6 x / \mathrm{N}$ \\
\hline & Samloti, 600 & 55738 & 27 & $6 x / \mathrm{N}$ \\
\hline & Ranital, 550 & 55739 & 27 & $6 x / \mathrm{N}$ \\
\hline & Pohara, 800 & 55740 & 27 & $6 x / \mathrm{N}$ \\
\hline
\end{tabular}


Cytomorphological studies in some members of tribe Paniceae (Poaceae)

Continuation of table 1

\begin{tabular}{|c|c|c|c|c|}
\hline Taxa & Locality, Altitude (m) & $\begin{array}{c}\text { Accession numbers } \\
\text { (PUN) }\end{array}$ & $\begin{array}{c}\text { Meiotic chromosome } \\
\text { number }(n) \\
\text { (Figure number) }\end{array}$ & $\begin{array}{c}\text { Ploidy level/Meiotic } \\
\text { course }\end{array}$ \\
\hline \multirow{4}{*}{$\begin{array}{l}\text { E. crus-pavonis } \\
\text { (H.B.K.) Schult. } \\
\text { E. frumentacea Link }\end{array}$} & Bhanala, 800 & 55272 & 27 (Fig. 14) & $6 x / \mathrm{N}$ \\
\hline & Rehlu, 950 & 55732 & 27 & $6 x / \mathrm{N}$ \\
\hline & Bada Gran, 3500 & 52634 & 27 (Fig. 15) & $6 x / \mathrm{N}$ \\
\hline & Bhagsunaag, 1650 & 53592 & 27 & $6 x / \mathrm{N}$ \\
\hline \multirow{4}{*}{$\begin{array}{l}\text { Isachne albens Trin. } \\
\text { Oplismenus burman- } \\
\text { nii (Retz.) P. Beauv. }\end{array}$} & Andretta, 1250 & 54740 & 5 (Fig. 16) & $2 x / \mathrm{N}$ \\
\hline & Ranehar, 850 & 52625 & 9 (Fig. 17) & $2 x / \mathrm{N}$ \\
\hline & Dharamsala, 1600 & 53533 & 9 & $2 x / \mathrm{N}$ \\
\hline & Paprola, 1400 & 55742 & 9 & $2 x / \mathrm{N}$ \\
\hline \multirow{3}{*}{$\begin{array}{l}\text { O. compositus L. P. } \\
\text { Beauv. }\end{array}$} & Dharamsala, 1600 & 52623 & 27 (Fig. 18) & $6 x / \mathrm{N}$ \\
\hline & Bhagsunaag, 1650 & 53531 & 27 & $6 x / \mathrm{N}$ \\
\hline & Khaniara, 1750 & 53532 & 36 (Fig. 19) & $8 x / \mathrm{N}$ \\
\hline \multirow{3}{*}{$\begin{array}{l}\text { O. undulatifolius } \\
\text { (Ard.) P. Beauv. }\end{array}$} & Chhota Bhangal, 2000 & 55295 & 27 (Fig. 20) & $6 x / \mathrm{N}$ \\
\hline & Majhera, 1550 & 55736 & 27 & $6 x / \mathrm{N}$ \\
\hline & Loharari, 2500 & 55737 & 27 & $6 x / \mathrm{N}$ \\
\hline \multirow{4}{*}{$\begin{array}{l}\text { Paspalidium flavidum } \\
\text { (Retz.) A. Camus }\end{array}$} & Suliali, 500 & 55298 & 27 (Fig. 21) & $6 x / \mathrm{N}$ \\
\hline & Palampur, 1563 & 55306 & 27 & $6 x / \mathrm{N}$ \\
\hline & Dehra, 650 & 55307 & 27 & $6 x / \mathrm{N}$ \\
\hline & Rajpura, 1300 & 55734 & 27 & $6 x / \mathrm{N}$ \\
\hline \multirow{5}{*}{$\begin{array}{l}\text { Paspalum dilatatum } \\
\text { Poir. }\end{array}$} & Chhota Bhangal, 2000 & 54751 & 30 (Fig. 23) & $6 x / \mathrm{ABN} * *$ \\
\hline & Bhanala, 800 & 54752 & 30 & $6 x / \mathrm{ABN}$ \\
\hline & Bada Gran, 3500 & 54770 & 30 & $6 x / \mathrm{ABN}$ \\
\hline & Patti, 890 & 54771 & 30 & $6 x / \mathrm{ABN}$ \\
\hline & Ranehar, 850 & 54778 & 30 & $6 x / \mathrm{ABN}$ \\
\hline \multirow[t]{3}{*}{ P. distichum $L$. } & Dharamsala, 1600 & 52630 & $2 n=50($ Fig. 24,25) & $5 x / \mathrm{ABN}$ \\
\hline & Bhagsunaag, 1650 & 53540 & $2 n=50$ & $5 x / \mathrm{ABN}$ \\
\hline & Majhera, 1550 & 55741 & $2 n=50$ & $5 x / \mathrm{ABN}$ \\
\hline $\begin{array}{l}\text { Urochloa panicoides } \\
\text { P. Beauv. }\end{array}$ & Dehra, 650 & 52632 & 24 (Fig. 22) & $6 x / \mathrm{ABN}$ \\
\hline
\end{tabular}

* $\mathrm{N}=$ Normal Meiosis, ${ }^{* *} \mathrm{ABN}=$ Abnormal Meiosis.

some significant differences are noted for some characters of the presently worked out cytotypes (Figs 34a-35b, Table 2).

D. granularis (Trin.) Henr. The species is commonly known as crabgrass. The populations worked out at present are found to be common in open fields in district Kangra within altitudinal range of $600-2700 \mathrm{~m}$. It is easily recognized by leaves $7-$ $8 \mathrm{~cm}$ long, $3 \mathrm{~mm}$ broad, acute at tip and tip of the pedicel somewhat thickened, without a rim of hairs. The present chromosome count of $n=36$ in the species is the first ever record of an octoploid cytotype on world-wide basis against the previous reports of only tetraploid cytotype with $2 n=36$ that too mainly from different parts of north India [14, 24] except for one report [25] from Thailand.

D. longiflora (Retz.) Pers. The species is commonly known as Indian crab grass. The pres- ently worked out populations are found to be common along the roadsides and in the rice fields within altitude range of 500-2000 $\mathrm{m}$ in district Kangra. The species is characterized by culms creeping and rooting at nodes and inflorescence of 2-3 racemes upto $7 \mathrm{~cm}$ long. Cytologically speaking, this grass is based on $x=9$ and with $n=$ $=9$ is found to be at diploid level in conformity with reports from India and outside India. The other different cytotypes for the species with $2 n=$ $=36,54$ and 72 at $4 x, 6 x$, and $8 x$ levels along with one report of possibly aneuploid cytotype, $2 n=34$ are also reported in the literature but mostly from outside India.

D. setigera Roth ex Roem. \& Schult. The presently worked out populations are found along the roadsides at an altitudinal range of 500-3000 m in district Kangra. The species is characterized 
Table 2

Detailed morphological comparison of cytotypes of three different species of tribe Paniceae from district Kangra of Himachal Pradesh (Western Himalayas)

\begin{tabular}{|c|c|c|}
\hline Character & Cytotype A $(n=27)$ & Cytotype B $(n=36)$ \\
\hline \multicolumn{3}{|c|}{ Digitaria adscendens } \\
\hline Plant height (cm) & $32-34$ & $40-44$ \\
\hline Number of internodes & $4-5$ & $5-6$ \\
\hline Size of internode $(\mathrm{cm})$ & $3.5-4.5$ & $5.2-6.0$ \\
\hline Length of sheath $(\mathrm{cm})$ & $3.2-5.8$ & $6.8-8.5$ \\
\hline Length of lamina $(\mathrm{cm})$ & $4.0-5.5$ & $8.0-8.5$ \\
\hline Width of lamina $(\mathrm{mm})$ & $3-5$ & $6-8$ \\
\hline Hairyness of lamina & Absent & $\begin{array}{l}\text { Present on both upper and } \\
\text { lower sides }\end{array}$ \\
\hline Type of Ligule & Hairs absent & A fringe of hairs \\
\hline Stomata Size $(\mu \mathrm{m})$ & $32.24 \times 21.27$ & $41.79 \times 25.78$ \\
\hline $\begin{array}{l}\text { Stomatal frequency on upper/lower surface of leaf } \\
\left(\mathrm{mm}^{2}\right)\end{array}$ & $7.48 \times 5.68$ & $8.18 \times 5.86$ \\
\hline Stomatal index of upper/lower surface of leaf $(\mu \mathrm{m})$ & $17.77 \times 13.34$ & $24.67 \times 18.47$ \\
\hline Length of spike $(\mathrm{cm})$ & $6.4-8.2$ & $8.5-10$ \\
\hline Length of spikelet (mm) & $3.0-3.5$ & $3.5-4.0$ \\
\hline Lemma Size $(\mathrm{mm})$ & $2.8-3.0$ & $3.8-4.0$ \\
\hline Palea Size $(\mathrm{mm})$ & $1.6-1.9$ & $2.2-2.8$ \\
\hline Pollen Fertility (\%) & 98 & 92 \\
\hline Pollen Size $(\mu \mathrm{m})$ & $30.53 \times 28.02$ & $39.57 \times 38.52$ \\
\hline \multicolumn{3}{|c|}{ D. setigera } \\
\hline Plant height $(\mathrm{cm})$ & $38-40$ & $45-48$ \\
\hline Number of internodes & $4-5$ & $7-8$ \\
\hline Size of internode $(\mathrm{cm})$ & $7.2-8.0$ & $10-12$ \\
\hline Length of sheath $(\mathrm{cm})$ & $6.0-8.5$ & $9.2-10$ \\
\hline Length of lamina $(\mathrm{cm})$ & $7.2-8.3$ & $10-11$ \\
\hline Hairyness of lamina & $\begin{array}{l}\text { Present on lower side } \\
\text { only }\end{array}$ & Absent \\
\hline Stomata Size $(\mu \mathrm{m})$ & $29.28 \times 20.93$ & $44.54 \times 28.18$ \\
\hline $\begin{array}{l}\text { Stomatal frequency on upper/lower surface of leaf } \\
\left(\mathrm{mm}^{2}\right)\end{array}$ & $5.68 \times 4.26$ & $8.34 \times 5.94$ \\
\hline Stomatal index of upper/lower surface of leaf $(\mu \mathrm{m})$ & $20.00 \times 16.85$ & $27.74 \times 22.72$ \\
\hline Length of spike $(\mathrm{cm})$ & $8.3-9.4$ & $10-10.5$ \\
\hline Length of spikelet (mm) & $3.0-3.5$ & $3.5-4.0$ \\
\hline Lemma Size $(\mathrm{mm})$ & $2.2-2.6$ & $2.5-3.0$ \\
\hline Palea Size $(\mathrm{mm})$ & $1.0-1.4$ & $1.8-2.2$ \\
\hline Pollen Fertility (\%) & 96 & 100 \\
\hline Pollen Size $(\mu \mathrm{m})$ & $38.42 \times 35.08$ & $46.85 \times 43.52$ \\
\hline
\end{tabular}

Plant height $(\mathrm{cm})$

Number of internodes

Size of internode $(\mathrm{cm})$

Length of sheath $(\mathrm{cm})$

Length of lamina $(\mathrm{cm})$

Width of lamina $(\mathrm{mm})$

Stomata Size $(\mu \mathrm{m})$
Oplismenus compositus

$\begin{array}{lc}34-36 & 50-56 \\ 4-5 & 6-7 \\ 4.0-4.3 & 4.2-4.5 \\ 4.5-4.7 & 5.5-5.8 \\ 3.2-7.5 & 9.5-12.0 \\ 6.0-12.5 & 13.0-13.3 \\ 42.24 \times 36.41 & 48.39 \times 25.52\end{array}$


Continuation of table 2

\begin{tabular}{l|ll}
\hline \multicolumn{1}{c|}{ Character } & Cytotype A $(n=27)$ & \multicolumn{1}{c}{ Cytotype B $(n=36)$} \\
\hline $\begin{array}{l}\text { Stomatal frequency on upper/lower surface } \\
\text { of leaf }\left(\mathrm{mm}^{2}\right)\end{array}$ & $7.48 \times 6.75$ & $8.44 \times 4.78$ \\
Stomatal index of upper/lower surface & $17.19 \times 12.38$ & $23.54 \times 18.12$ \\
of leaf $(\mu \mathrm{m})$ & & \\
Length of awn $(\mathrm{cm})$ & $7.2-16.4$ & $16.0-23.8$ \\
Length of spikelet $(\mathrm{mm})$ & 3.0 & 4.0 \\
Length of Bristle $(\mathrm{mm})$ & $7.0-8.0$ & $12.8-13.0$ \\
Lemma Size $(\mathrm{mm})$ & 2.7 & 3.4 \\
Palea Size $(\mathrm{mm})$ & 1.8 & 2.6 \\
Pollen Fertility $(\%)$ & 85 & 92 \\
Pollen Size $(\mu \mathrm{m})$ & $32.39 \times 30.29$ & $47.26 \times 43.67$ \\
\end{tabular}

by racemes densely pubescent with or without a few long white hairs and spikelets elliptic-acute. Two cytotypes, one at hexaploid level with $n=$ $=27$ in five populations and another at octoploid level with $n=36$ in four populations have been cytologically investigated at present in conformity with earlier many reports from India and one report of $2 n=72$ from Pakistan by [26]. Another cytotype at tetraploid level with $2 n=36$ has also been earlier known from north India by [27-29]. The cytotypes investigated at present also differ for some morphological characters (Figs 36a-37b, Table 2).

D. stricta Roth ex Roem. et Schult. The populations worked out at present are found to be common along the roadsides in rocky crevices within altitudinal range of $600-1500 \mathrm{~m}$ in district Kangra. The grass has good fodder value. The species is characterized by culm erect; tip of the pedicel cupuliform with hairs on the rim and distinct upper glume. The gametic chromosome number for the species is reported to be $n=36$ at octoploid level in conformity with single earlier report by [30] from north India. Previously, two reports of diploid cytotype with $2 n=18[31,32]$ and polyploid cytotypes with $2 n=36(4 x)$ and $2 n=54(6 x)$ are known, that too mainly from India.

D. violascens Link. The populations worked out at present are found to be common in shady moist places along the roadsides between altitudes of $800-2000 \mathrm{~m}$ in district Kangra. The species is characterized by culms erect and inflorescence of 2-6 racemes, $4-10 \mathrm{~cm}$ long. Cytologically speaking, this grass with $n=18$ is found to be tetraploid in conformity with the earlier report of $2 n=36$ reported from India and outside India along with single diploid report of $2 n=18$ from India by [7, 33].

Echinochloa colonum (L.) Link. The species is commonly known as Jungle rice or Shama millet, is a common weed of rice fields and moist habitats. The species has good fodder value, grains are eaten by poorer people. The presently worked out populations are commonly found in damp rich soils in district Kangra within altitudinal range of 500-3000 m. The species is characterized by spikes distant; spikelets more or less hairy and lower lemma and upper glume equally acute, not awned. Cytologically, the genus is based on $x=7,8,9$, 10 with 9 remaining to be dominant base number. This species is reported to exhibit $n=27$ at hexaploid level in conformity with bulk of previous reports from different parts of the world. The other chromosome numbers $2 n=24$, 32, 36, 48, 52, 54, 56, 72, 96 and 108 showing intraspecific polyploid and aneuploid cytotypes ranging from $3 x$ to $12 x$ levels are previously known but mainly from different parts of India.

E. crus-galli (L.) P. Beauv. The species commonly known as barnyard grass is a troublesome weed in the temperate countries. However due to its lush nature, acts as valuable forage plant. The populations worked out at present are commonly found in various moist habitats. The species is characterized by panicle erect, rather stiff; lower lemma and upper glume acuminate and lower lemma shortly awned. The species is reported to be hexaploid with $n=27$ in conformity with 

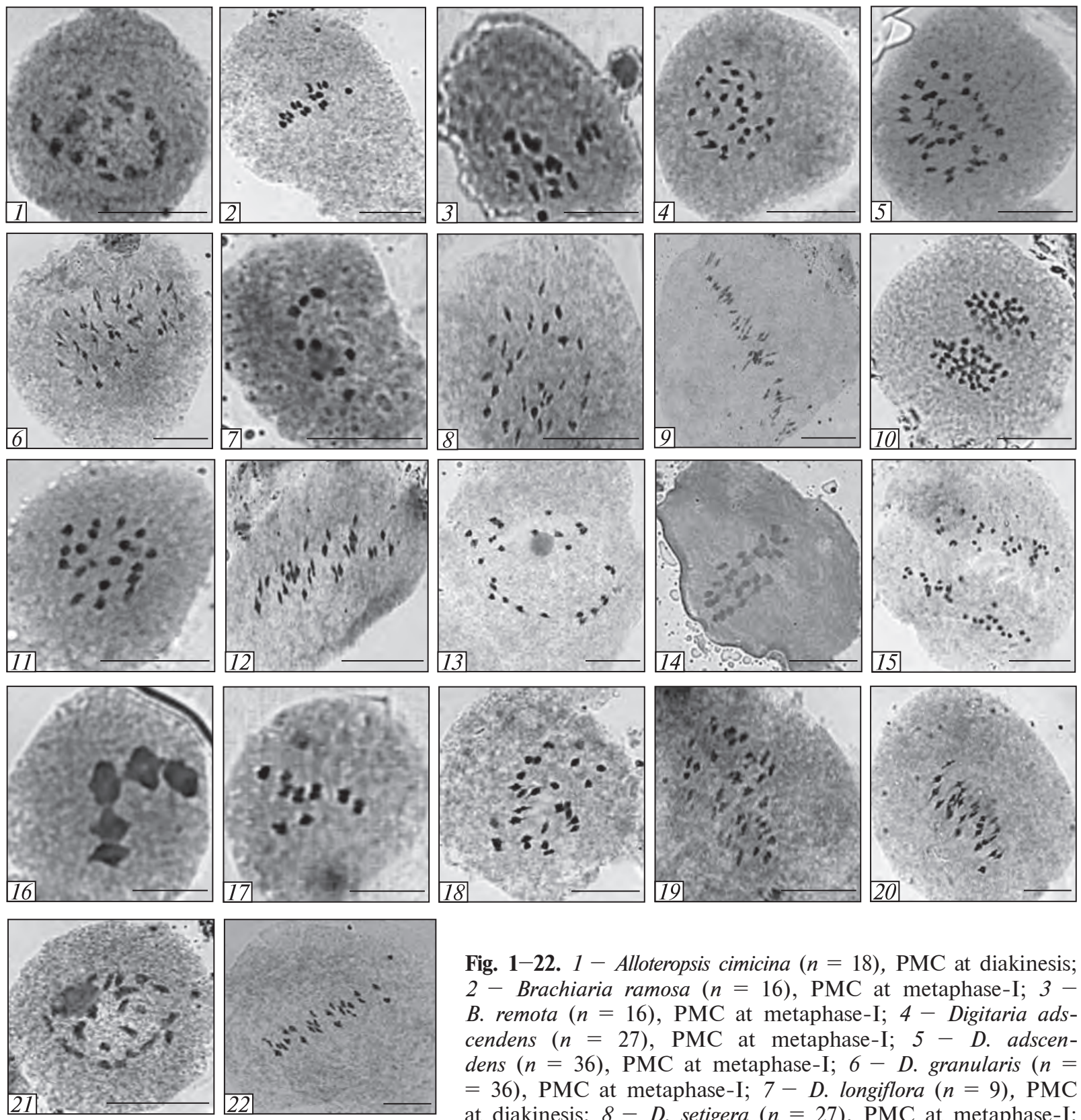

Fig. 1-22. 1 - Alloteropsis cimicina $(n=18)$, PMC at diakinesis; 2 - Brachiaria ramosa $(n=16)$, PMC at metaphase-I; 3 B. remota $(n=16)$, PMC at metaphase-I; 4 - Digitaria adscendens $(n=27)$, PMC at metaphase-I; $5-D$. adscendens $(n=36)$, PMC at metaphase-I; $6-D$. granularis $(n=$ $=36)$, PMC at metaphase-I; $7-D$. longiflora $(n=9)$, PMC at diakinesis; $8-D$. setigera $(n=27)$, PMC at metaphase-I; 9 - D. setigera $(n=36)$, PMC at metaphase-I; $10-$ D. stricta $(n=36), \mathrm{PMC}$ at anaphase-I; $11-D$. violascens $(n=18)$, PMC at metaphase-I; $12-$ Echinochloa colonum $(n=27)$, PMC at metaphase-I; $13-$ E. crus-gallii $(n=27)$, PMC at diakinesis; $14-$ E. crus-pavonis $(n=$ $=27)$, PMC at metaphase-I; $15-$ E. frumentacea $(n=27)$, PMC at anaphase-I; $16-$ Isachne albens $(n=5)$, PMC at metaphase-I; $17-$ Oplismenus burmannii $(n=9)$, PMC at metaphase-I; $18-O$. compositus $(n=27)$, PMC at metaphase-I; $19-O$. compositus $(n=36)$, PMC at metaphase-I; $20-0$. undulatifolius $(n=27)$, PMC at metaphase-I; $21-$ Paspalidium flavidum $(n=27)$, PMC at diakinesis; $22-$ Urochloa panicoides $(n=24)$, PMC at metaphase-I. Scale $-10 \mu \mathrm{m}$ 

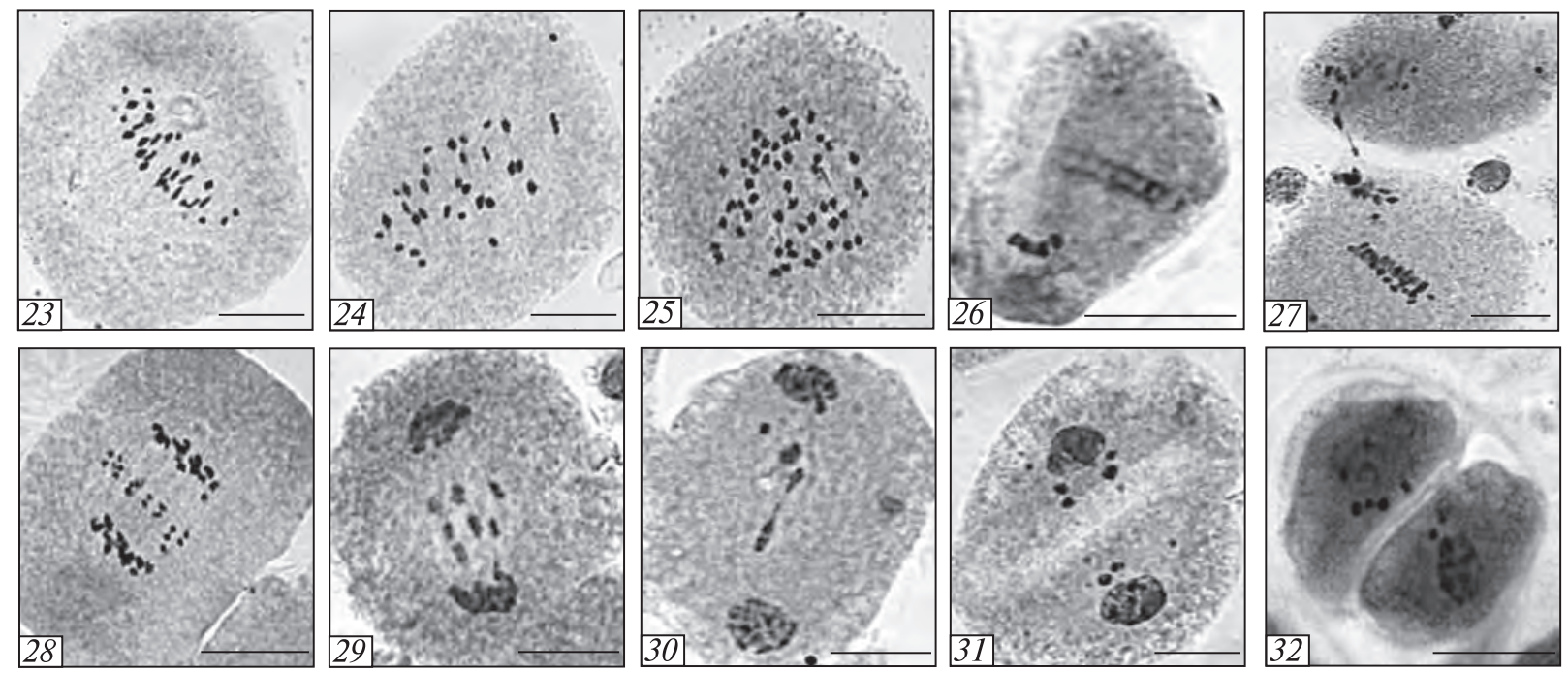

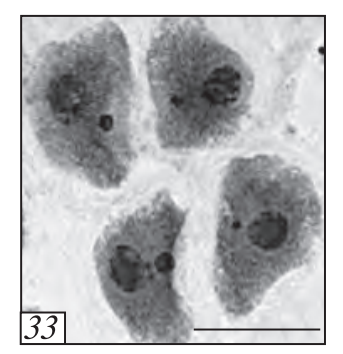

Fig. 23-33. 23 - Paspalum dilatatum $(n=30)$, PMC at metaphase-I; $24-P$. distichum $(n=20 \mathrm{II}+10 \mathrm{I}), \mathrm{PMC}$ at metaphase-I; $25-P$. distichum $(2 n=50), \mathrm{PMC}$ at anaphase-I; Fig. 26-30. Paspalum dilatatum (26- PMC at metaphase-I showing the unoriented bivalents; 27 - PMCs at metaphase-I showing chromatin transfer; 28 - PMC showing laggards at A-I; 29- PMC showing laggards at T-I; 30-PMC showing chromatin bridge and a laggard at telophase-I). Fig. 31-33. P. distichum (31- PMC showing laggards at late telophase-I; $32-$ diads with 6-7 micronuclei; 33 - tetrad with micronuclei). Scale $=10 \mu \mathrm{m}$

previous reports reported from India and outside India by various workers. The other chromosome number reports as $2 n=18,36,42,48,50$ at $2 x$, $4 x, 6 x$ levels are available in literature as multiple references from India as well as outside India. However, single reports are available for certain polyploid cytotypes as $2 n=38$ [34]; $2 n=56$ [35]; $2 n=72$ [36]; $2 n=90$ [26] from outside India only.

E. crus-pavonis (H.B.K.) Schult. The populations worked out at present have been found near water places in district Kangra within the altitudinal range of $500-1000 \mathrm{~m}$. The species is characterized by panicle dense with numerous racemes and very crowded spikelets $2.5-3 \mathrm{~mm}$ long and usually awned. The present chromosome count of $n=27$ in the species is a new record of a hexaploid cytotype on India basis against the previous report of [37] from east Africa. The other chromosome numbers as $2 n=18$ as $2 x$ [38] and $2 n=36$ as $4 x$ [39-42] are also known from outside India.

E. frumentacea Link. The presently worked out populations are commonly found in the wet and moist open fields of district Kangra. The species is characterized by tall and robust nature; spikelets densely crowded and ligules entirely absent. Cytologically speaking, based on $x=9$ this species with $n=27$ is found to be at hexaploid level in conformity with various previous reports available from India and outside India. The other different cytotypes for the species based on $x=$ $=7,2 n=56$ at $8 x$ [43]; $x=8,2 n=48$ at $6 x$ [44] and $x=9,2 n=36$ at $4 x[45]$ are also reported in the literature suggesting polybasic nature of the species.

Isachne albens Trin. The presently worked out populations are commonly found as a weed in wheat fields. The species is characterized by sheaths smooth; stiff leaves; panicle with many spikelets and white florets. The genus is based on $x=5$. The present chromosome count of $n=5$ in the species is the first ever record of a diploid cytotype on world-wide basis against few reports as $2 n=40$ at octoploid level $[33,46]$ from Western Himalayas and Punjab plains, respectively.

Oplismenus burmanii (Retz.) P. Beauv. The presently worked out populations are commonly 
H. Kaur, S. Kumari, R.C. Gupta

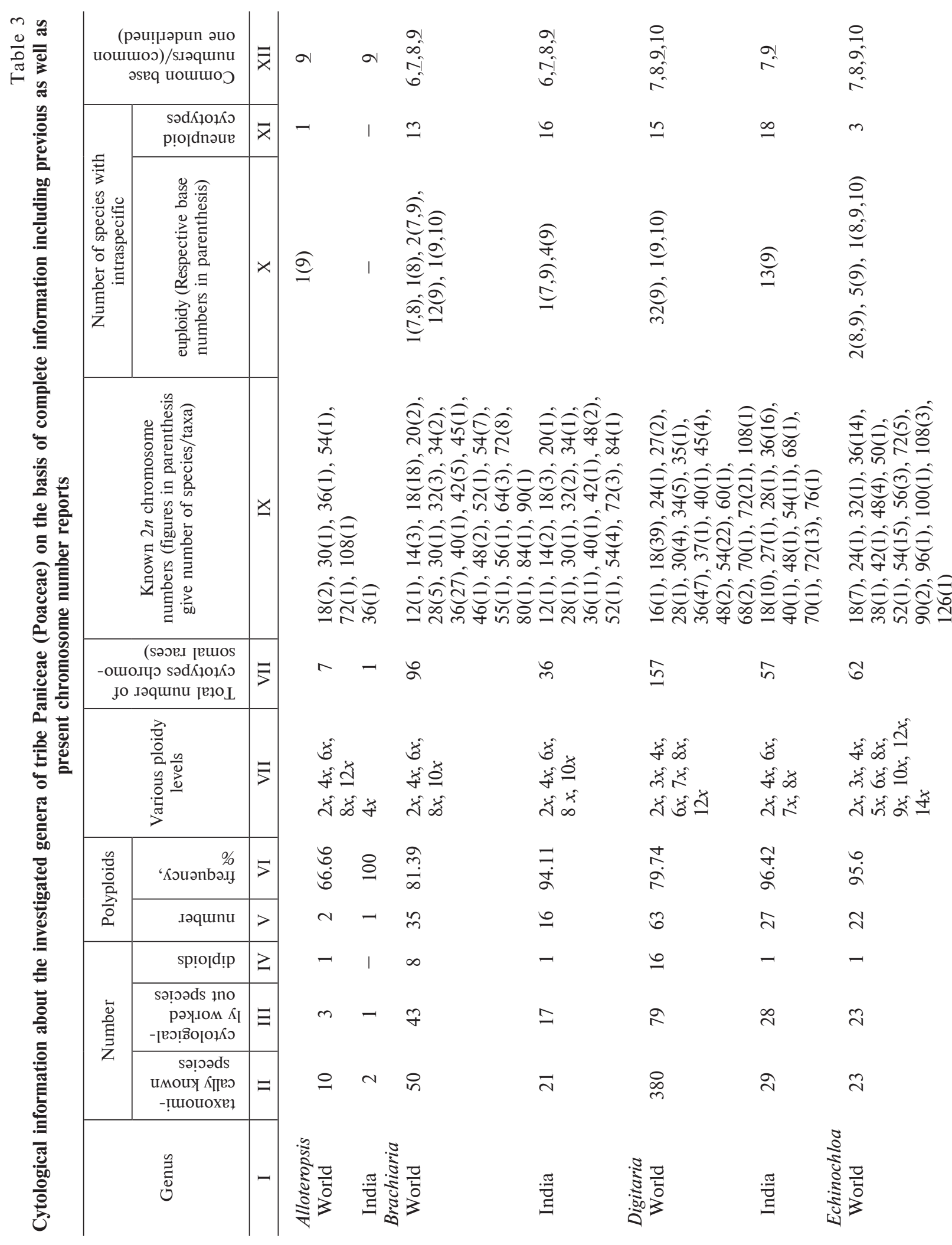




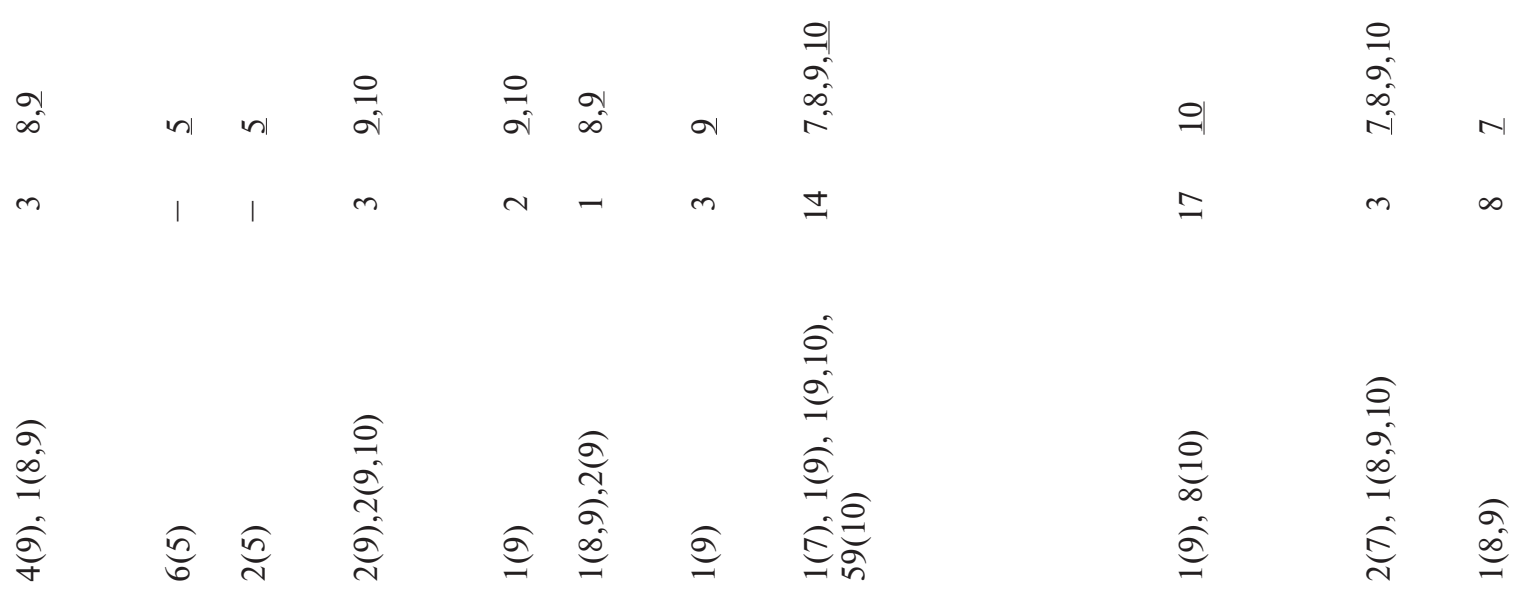

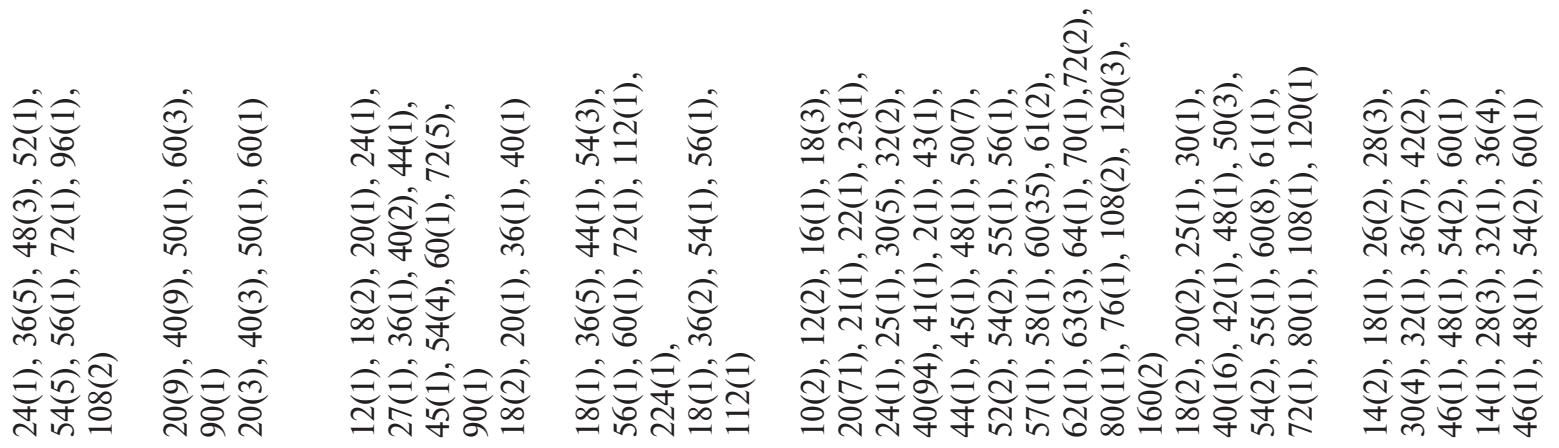

\begin{tabular}{|c|c|c|c|c|c|c|c|c|c|c|}
\hline$\gtrsim$ & $\ddot{\lambda}$ & $\infty$ & $\approx$ & in & 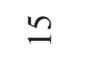 & 6 & $\stackrel{\overbrace{}}{\stackrel{\overbrace{}}{ }}$ & $\mathscr{F}$ & $\hat{\imath}$ & \pm \\
\hline 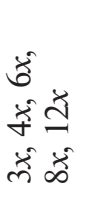 & 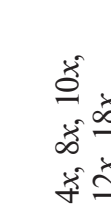 & 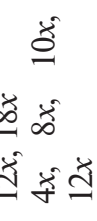 & 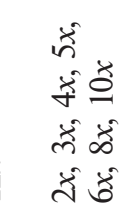 & $\begin{array}{l}\breve{x} \\
\breve{c} \\
\breve{y}\end{array}$ & 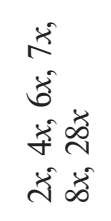 & 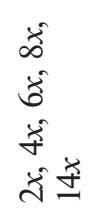 & 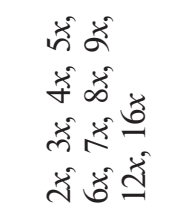 & 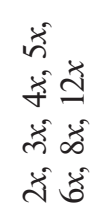 & $\begin{array}{l}\breve{b} \\
\breve{f} \\
\breve{d} \\
\tilde{y} \\
\breve{d}\end{array}$ & $\begin{array}{l}\breve{\sigma} \\
\breve{f} \\
\check{\jmath}\end{array}$ \\
\hline 8 & ○ & $\cong$ & $\cong$ & @ & 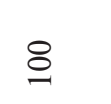 & 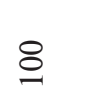 & $\begin{array}{l}\infty \\
\infty \\
\infty\end{array}$ & $\begin{array}{l}\stackrel{n}{q} \\
\dot{a}\end{array}$ & $\vec{i}$ & $\stackrel{n}{\infty}$ \\
\hline 6 & $\underline{0}$ & 0 & 6 & $\sim$ & $r$ & $n$ & $\stackrel{q}{\exists}$ & $\vec{\sim}$ & $\simeq$ & $r$ \\
\hline 1 & I & 1 & 1 & 1 & 1 & 1 & $\widehat{b}$ & - & $\sim$ & - \\
\hline 6 & $\underline{0}$ & 6 & 0 & $\sim$ & $r$ & $n$ & $\underset{\infty}{\nsubseteq}$ & $\approx$ & \pm & $\infty$ \\
\hline - & 8 & $\approx$ & $\cong$ & $\nabla$ & ণ & $n$ & $\stackrel{\wp}{i}$ & $\approx$ & $\approx$ & $\infty$ \\
\hline 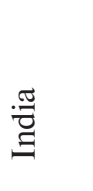 & 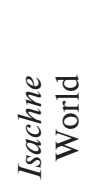 & $\stackrel{\mathscr{\sigma}}{g}$ & 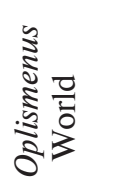 & $\Xi$ & 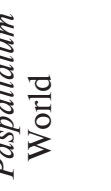 & 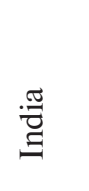 & 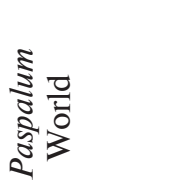 & $\stackrel{\frac{\pi}{\sigma}}{\Xi}$ & $\begin{array}{l}\frac{5}{5} \\
\frac{5}{5} \\
53\end{array}$ & $\stackrel{\Xi}{\Xi}$ \\
\hline
\end{tabular}



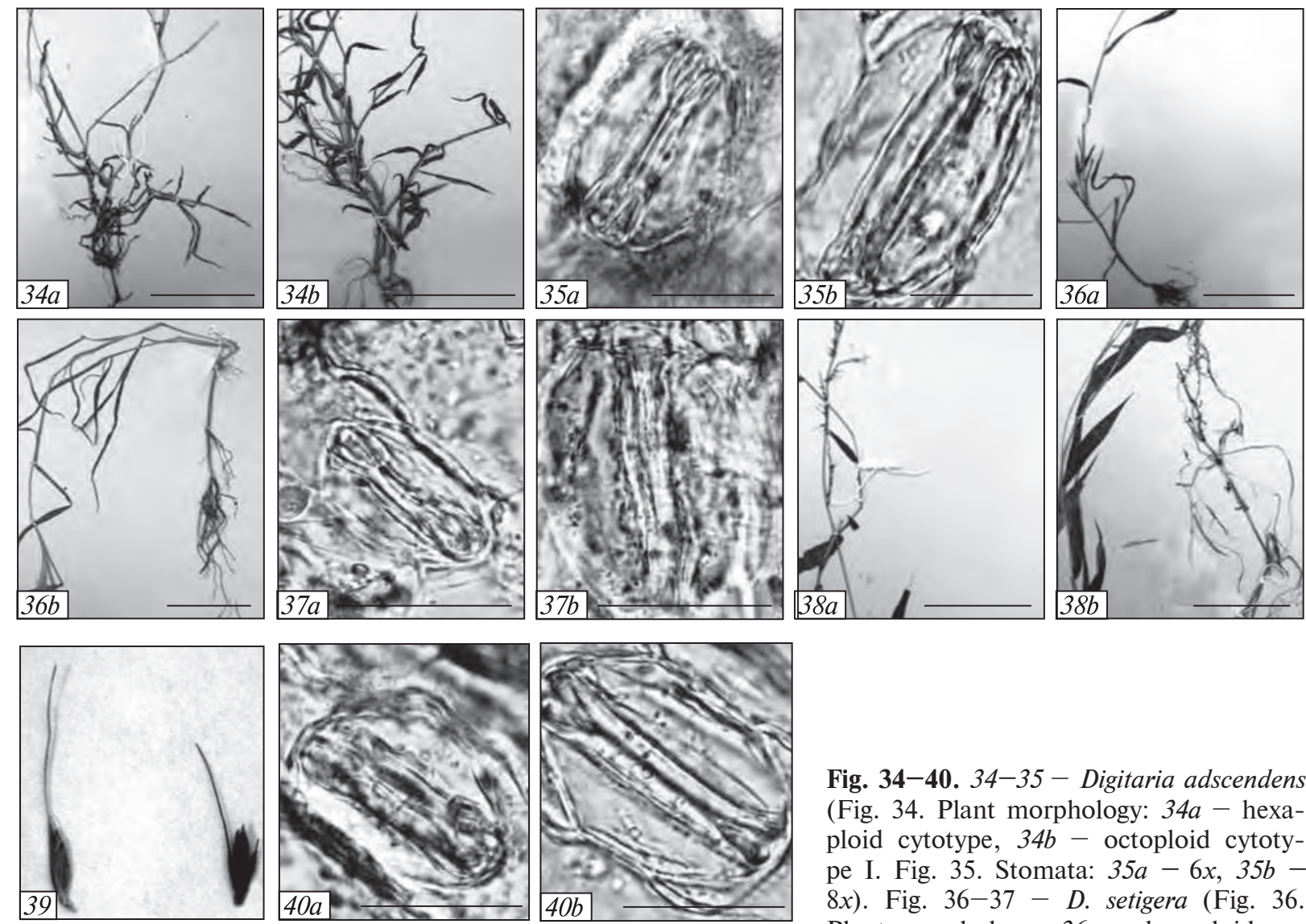

Fig. 34-40. 34-35 - Digitaria adscendens (Fig. 34. Plant morphology: $34 a-$ hexaploid cytotype, $34 b-$ octoploid cytotype I. Fig. 35. Stomata: $35 a-6 x, 35 b-$ $8 x$ ). Fig. 36-37 - D. setigera (Fig. 36. Plant morphology, $36 a$ - hexaploid cytotype, $36 b-$ octoploid cytotype. Fig. 37. Stomata: $37 a-6 x, 37 b-8 x$ ). Fig. 38-40. Oplismenus compositus (Fig. 38. Plant morphology: $38 a-$ hexaploid cytotype, $38 b-$ octoploid cytotype. Fig. 39. Spikelets $-6 x$ (Right) and $8 x$ (Left). Fig. 40. Stomata: $40 a-6 x, 40 b-8 x$ )

found on rocks along roadsides between the altitudinal range of $800-1500 \mathrm{~m}$ in district Kangra. The species is characterized by awns pale, barbellate, capillary and flexuous. Cytologically, the genus is dibasic with $x=9$ and 10 but 9 remains predominant base number. This species is found to be at diploid level with $n=9$ in conformity with many earlier reports from India and outside India. Another diploid cytotype based on $x=$ $=10$ with $2 n=20$ is reported by [47] from Africa and [48] from Pachmari hills along with different polyploid and aneuploid cytotypes known with $2 n=36,40,44,54$ and 72 exhibiting $4 x$ to $8 x$ levels from different parts of the world.

O. compositus L. P. Beauv. The species is commonly known as running mountain grass and is used as an excellent fodder grass. The presently worked out populations are commonly found to be growing gregariously in open shady places of district Kangra. The species is characterized by inflorescence of racemes of spikelets alternate along a long or short rachis and awns reddish, smooth, viscid, stiff. Based on $x=9$, this species is worked out in the form two cytotypes, one with $n=27$ at hexaploid level in conformity with various previous reports available mainly from India including single report [25] from Thailand and another one, with $n=36$ at octoploid level previously also known from different parts of the world. The other cytotypes, $2 n=18(2 x)$ based on $x=9$ and $2 n=40(4 x)$ based on $x=10$ are also reported in the literature. A single report of presence of quite high frequency of $\mathrm{B}$ chromosomes as $2 n=54+6-13 \mathrm{~B}$ at hexaploid level is also known from earlier reports by [7] from Central and Eastern Himalayas. The cyto- 
types investigated at present also show some of the significant morphological differences (Figs $38 a-40 b$, Table 2).

O. undulatifolius (Ard.) P. Beauv. The species is commonly known as wavyleaf basket grass. The presently worked out populations are commonly found on the foot of rocks along roadsides in district Kangra. The species is characterized by inflorescence of groups of fascicled spikelets alternate along the axis. This species with $n=$ $=27$ is also based on $x=9$ and is found to be at hexaploid level in conformity with various reports from India and outside India. However, diploid cytotype with lower chromosome number $2 n=12$ is also known for the species in literature by [49] from Shandong. Another single report of presence of 2B-chromosomes in hexaploid cytotype is reported by [28] from east India.

Paspalidium flavidum (Retz.) A. Camus. The species commonly called yellow watercrown grass is found mostly in moist and shady places of the plains and hilly areas of district Kangra. The species is characterized by spikes shorter than the internodes and upper glume not as long as upper lemma. Cytologically, the genus is based on $x=$ $=8$ and 9 with later being more common. The presently worked out species is noted to have $n=$ $=27$ at hexaploid level in conformity with the earlier reports, that too mostly from India. The species also exhibits diploid and tetraploid chromosome numbers as $2 n=18,36$ from India and outside India along with aneuploids at polyploid level $2 n=$ $=44$ [34] and $2 n=56$ [32, 50] only from India.

Paspalum dilatatum Poir. The species is commonly known as dallisgrass, used as a good pasture grass. The populations worked out at present have been found near water places in district Kangra within the altitudinal range of $800-3500 \mathrm{~m}$. The species is generally characterized by its tufted and perennial habit; geniculate stem at the base; 3-5 racemes and dull-green or purplish spikelets. Cytologically, the genus is based on $x=7,8,9$ and 10 with the last number being most common base number. This species is also based on $x=10$ and is found to be at hexaploid level with $n=30$ in conformity with majority of reports available from outside India plus two reports from north India by [27] and south India by [6]. The other polyploid cytotypes with $2 n=40,50$ are also previously known for the species but mainly from outside India except for the single report for hexaploid cytotype with $2 n=$ $=54$ by [51] from India. The meiotic course in all the populations is found to be abnormal with the presence of various abnormalities in the form of cytomixis, chromatin stickiness, unoriented bivalents, inter-bivalent connections, bridges and laggards at different stages of meiosis (Figs 26-30). These abnormalities result into the formation of anomalous microsporogenesis and heterogenous sized pollen grains.

$\boldsymbol{P}$. distichum L. The species is commonly known as knot grass. The presently worked out populations are found to be common near water places within the altitude range of 1000-2000 m in district Kangra. The species is characterized by its aquatic habitat with rhizomes and long creeping stolons; erect culm and elliptic spikelets, twice as long as broad. The slender rhizomes of the species form loose mats and act as a soilbinder on the banks of the stream. The present chromosome count of $2 n=50$ represents a new cytotype for India and is in agreement with the previous report of $2 n=50$ by [52] from outside India. The other chromosome numbers as $2 n=$ $=20(2 x), 40(4 x), 120(12 x)$ representing euploid levels plus some aneuploid types at polyploid level $(2 n=52,54,57,58)$ are known from outside India along with few reports as $2 n=48(6 x), 60$ (6x) from India and outside India both plus one stray report of aneuploid cytotype at 6x level as $2 n=61$ [53, 54] from Kashmir in India only. All the populations studied at present show the abnormal meiotic behaviour with the presence of 6-10 univalents at diakinesis and M-I; bridges and laggards at anaphases and telophases and abnormal microsporogenesis showing diads with 6-7 micronuclei being quite common (Figs 3133 ). The phenomenon of cytomixis is also present but in low frequency $(8 \%)$. All these meiotic irregularities result into heterogenous sized pollen grains and reduced pollen fertility (54\%).

Urochloa panicoides P. Beauv. The species is commonly known as liverseed grass. The presently worked out populations are found to be common near shady and moist places in district Kangra. The species is characterized by lower glume less than half the length of the spikelet, without a fringe of bristles and glabrous. The genus is based on $x=7,8,9$, 10 with $x=7$ remaining to be 
most common number. But species worked out at present shows $n=24$ and based on $x=8$ is found to be at hexaploid level in conformity with the earlier reports of $2 n=48$ reported by various workers mostly from India except one report by [55] from outside India. The other chromosome numbers as $2 n=30$ at $3 x$ [56] and $2 n=42$ at $6 x$ level [57] are also reported in the literature from different parts of the world from outside India whereas $2 n=32$ at $4 x$ [6]; $2 n=46$ [58]; $2 n=$ 54 [29] and $2 n=60$ at $6 x$ levels [32] are known from India.

Discussion. It is pertinent to assess the frequency of cytologically worked out species of each genus studied at present before analyzing the chromosomal data accumulated from previous and present observations. The frequency of cytologically worked out species is available on world-wide and India basis as: $30 \%$ and $50 \%$ for Alloteropsis, $86 \%$ and $80.95 \%$ for Brachiaria, $20.78 \%$ and $96.55 \%$ for Digitaria, $100 \%$ and $85.71 \%$ for Echinochloa, $26.66 \%$ and $24 \%$ for Isachne, $40 \%$ and $50 \%$ for Oplismenus, $35 \%$ and $100 \%$ for Paspalidium, $73.6 \%$ and $100 \%$ for Paspalum and $56 \%$ and $100 \%$ for Urochloa, respectively (Table 3 , column II). In the species worked out at present, the chromosome numbers are noted as low as $n=5$ (1 species), $n=9$ (2 species), $n=16$ (2 species), $n=18$ ( 2 species), $n=24$ ( 1 species), $n=25$ ( 1 species), $n=27$ (9 species), $n=30$ ( 1 species) and as high as $n=36$ (5 species). Out of these 21 species, Brachiaria remota $(n=16)$, Digitaria granularis $(n=36)$ and Isachne albens $(n=5)$ are added as new cytotypes on the world-wide basis and Echinochloa crus-pavonis $(n=27)$ and Paspalum distichum $(2 n=50)$ are pooled on India basis. The other sixteen species conforms to the earlier chromosomal reports in the literature.

It is noted that base numbers proposed by different workers for the tribe on the world-wide basis are: [59] as $x=7,9,10,12,15,17,19$; [3] as $x=7,9,10,15,17,19$; [60] as $x=5,7,8,9$, $10,17,19$, and [61] as $x=5,6,7,8,9,10,12$, $15,17,19$. Otherwise, $x=7,8,9$ and 10 are accepted as common base numbers by majority of the cytologists for this tribe [6, 28, 62]. Amongst these, base numbers $x=9$ is found to be the most common in occurance as evident from $79 \%$ [63] and $70 \%[28]$ species of the tribe followed by $x=$
$=10$ and $x=7$. For the presently worked out genera on the world-wide basis and on India basis, the base numbers are $x=5,6,7,8,9,10$. On the basis of present chromosome number reports for the species investigated here, $x=9$ seems to be the common base number $(71.42 \%)$ followed by $x=8(14.29 \%)$. The other basic numbers $x=$ $10(9.52 \%)$ and $x=5(4.76 \%)$ are comparatively low in frequency. Polyploidy is very widespread in grasses and has played an important role in their evolution as seen from ploidy level of these nine genera with variation exhibited from $2 x$ to $28 x$ level on the world-wide basis and $2 x$ to $14 x$ on India basis (Table 3, column VII). In the presently studied populations, the same explanation holds true, i.e. the polyploidy remaining to be the chief mode of survival i.e. $8.2 \%$ diploids against $91.8 \%$ polyploids in occurance.

A perusal of literature pertaining to these nine genera brings to light a high degree of chromosome number variation at inter- and intraspecific level representing the role of hybridization and polyploidization leading to well marked diversity. Based on specific previous and present information about chromosome numbers, the examples are known of the species belonging to these genera exhibiting intraspecific chromosome number variation in the form of diploid and /or polyploid cytotypes based either on single base number, e.g. $x=5$ (6 species of Isachne), $x=7$ (2 species of Urochloa), $x=8$ (Brachiaria kurzii, Paspalum punctatum), $x=9$ (Alloteropsis semialata, 12 species of Brachiaria, 32 species of Digitaria, 5 species of Echinochloa, 2 species of Oplismenus, 2 species of Paspalidium, Paspalum paspalodes) or two base numbers, e.g. $x=7,8$ (Brachiaria setigera), $x=7,9$ (2 species of Brachiaria), $x=8,9$ (2 species of Echinochloa, Paspalidium flavidum), $x=9,10$ (Brachiaria decumbens, Digitaria ascendens, 2 species of Oplismenus, Paspalum dilatatum) or even three base numbers, e.g. $x=8,9$, 10 (Echinochloa crus-gallii, Urochloa panicoides). The number of species showing aneuploid variations both at diploid and /or polyploid level also exist as noted in case of certain genera (Table 3, column XI) e.g. Alloteropsis cimicina, 13 species of Brachiaria, 15 species of Digitaria, 3 species of Echinochloa, 3 species of Oplismenus, Paspalidium flavidum, 14 species of Paspalum and 3 species of Urochloa.

ISSN 0564-3783. Цитология и генетика. 2013. № 2 
The morphological comparison of different hexaploid $(n=27)$ and octoploid $(n=36)$ cytotypes of the three species, Digitaria adscendens, D. setigera and Oplismenus compositus show some marked increase in some macro- (size of plant; leaves and inflorescence) and microcharacters (stomatal size; size of PMCs and size of pollen grains) with the increase in the level of ploidy.

Regarding the meiotic behavior, most of the species show normal meiosis with high pollen fertility. However, two species of Paspalum such as $P$. dilatatum and $P$. distichum are meiotically found to be very irregular. The irregularities consist of the occurrence of univalents at high frequency and abnormal meiotic course. Polyploidy, meiotic irregularity and probably apomixis are frequent in the predominantly tropical genus Paspalum [64]. The phenomenon of cytomixis and chromatin stickiness are considered to be the result of some genetic [65-67] and environmental factors [68] as well as genomic-environmental interaction $[69,70]$. It seems to be applicable to the presently studied populations. Chromatin transfer, desynapsis and various other meiotic irregularities seems to be the possible mechanisms responsible for the formation of heterogenous sized pollen grains and low pollen fertility.

The authors are grateful to the University Grants Commission, New Delhi for providing financial assistance under the DRS SAP III and FIST of DST as well as fellowship provided to H.K. under Maulana Azad National Fellowship Scheme. We are highly thankful to the Joint Director and Deputy Director, BSI and other staff of Herbarium of Dehra Dun for the help in the identification of the plant species.

\author{
H. Kaur, S. Kumari, R.C. Gupta
}

\section{ЦИТОМОРФОЛОГИЧЕСКОЕ ИЗУЧЕНИЕ НЕКОТОРЫХ ПРЕДСТАВИТЕЛЕЙ ТРИБЫ PANICEAE (POACЕAE) PAЙOHA KANGRA ШTATA HIMACHAL PRADESH (ЗАПАДНЫЕ ГИМАЛАИ)}

Проведено цитологическое исследование популяции из 21 вида, принадлежащих к 9 родам трибы Paniceae семейства Роасеае из цитологически не изученных областей Западных Гималаев (район Kangra штата Himachal Pradesh) для определения генетического разнообразия злаков. В мировом масштабе впервые осуществлены подсчеты хромосом для трех видов - Brachiaria remota $(n=16)$, Digitaria granularis $(n=36)$ и Isachne albens $(n=5)$. Аналогично, в масштабе Индии новые данные получены для двух видов - Echinochloa crus-pavonis $(n=27)$ и Paspalum distichum $(2 n=50)$. Сравнение различных эуплоидных цитотипов Digitaria adscendens, D. setigera и Oplismenus compositus показало значительную изменчивость их морфологии, отражающую увеличение некоторых признаков полиплоидных цитотипов. Изучение хода мейоза позволило установить, что он происходил нормально во всех популяциях с высокой фертильностью пыльцы, кроме Paspalum dilatatum и $P$. distichum, которые отличались аномальными мейозами и сниженной фертильностью пыльцы.

$$
\text { H. Kaur, S. Kumari, R.C. Gupta }
$$

\section{ЦИТОМОРФОЛОГІЧНЕ ВИВЧЕННЯ ДЕЯКИХ ПРЕДСТАВНИКІВ ТРИБИ РАNІСЕАЕ (POAСЕАЕ) РАЙОНУ KANGRA ШТАТУ HIMACHAL PRADESH (ЗАХІДНІ ГІМАЛАЇ)}

Проведено цитологічне дослідження популяції з 21 виду, що належать до 9 родів триби Paniceae сімейства Роасеае з цитологічно не вивчених областей Західних Гімалаїв (район Kangra штату Himachal Pradesh) для визначення генетичної різноманітності злаків. У світовому масштабі вперше здійснено підрахунки хромосом для трьох видів - Brachiaria remota $(n=16)$, Digitaria granularis $(n=36)$ i Isachne albens $(n=5)$. Аналогічно, в масштабі Індії нові дані отримані для двох видів Echinochloa crus-pavonis $(n=27)$ i Paspalum distichum $(2 n=50)$. Порівняння різних еуплоїдних цитотипів Digitaria adscendens, D. setigera i Oplismenus compositus показало значну мінливість їхньої морфології, що відображає збільшення деяких ознак поліплоїдних цитотипів. Вивчення ходу мейозу дозволило встановити, що він відбувався нормально в усіх популяціях з високою фертильністю пилку, крім Paspalum dilatatum i $P$. distichum, які відзначались аномальними мейозами та зниженою фертильністю пилку.

\section{REFERENCES}

1. Duke J.A. Handbook of Energy Crops, 1983.

2. Hartley $W$. Studies on the origin, evolution and distribution of the Gramineae I. The tribe Andropogoneae. Aust. J. Bot., 1958, vol. 6, pp. 116-128.

3. Bor N.L. The Grasses of Burma, Ceylon, India and Pakistan. Pergamon Press, 1960.

4. Chen C.C., Hsu C.C. Cytological studies of Taiwan grasses. I. Tribe Paniceae. Bot. Bull. Acad. Sin. Ser., 1961, vol. 2(2), pp. 101-110.

5. Phillips S.M., Chen S. Notes on grasses (Poaceae) 
for the Flora of China, II: Paniceae. Novon, 2003, vol. 13, pp. 467-470.

6. Christopher J., Abraham A. Study on the cytology and phylogeny of South Indian grasses. III. Subfamily VI: Panicoideae, tribe(i) the Paniceae. $C y$ tologia, 1976, vol. 41, pp. 621-637.

7. Mehra P.N., Sharma, M.L. Cytological studies in some Central and Eastern Himalayan grasses. Cytologia, 1975, vol. 40, pp. 75-89.

8. Mehra P.N., Sharma M.L. Cytological studies on some grasses of Kashmir. Cytologia, 1977, vol. 42, pp. 111-123.

9. Koul K.K. In IOPB chromosome number reports XCIX. Taxon, 1988, vol. 37(2), pp. 399.

10. Sharma M.L., Sharma K. Cytological studies in the North Indian grasses. Cytologia, 1979, vol. 44, pp. 861872.

11. Khosla P.K., Mehra P.N. In IOPB Chromosome Number Reports XLII. Taxon, 1973, vol. 22, pp. 647654.

12. Sobti S.N., Verma V., Rao B.L., Pushpangadan P. In IOPB Chromosome Number Reports LXV. Taxon, 1979, vol. 28, pp. 627.

13. Sharma M.L., Kumar P. In IOPB Chromosome Number Reports LXIX. Taxon, 1985, vol. 29, pp. 705-706.

14. Sharma M.L., Kaur S. In IOPB Chromosome Number Reports LXIX. Taxon, 1980, vol. 29, pp. 703-730.

15. Fedorov An.A. Academy of Science of USSR Komarov. Botanical Institute, Leningard, 1974.

16. Kumar V., Subramaniam B. Chromosome atlas of flowering plants of the Indian subcontinent, Vol.II., Monocotyledons, BSI, Calcutta, 1986.

17. Web: Missouri Botanical Gardens, Nomenclatural database http://mobot.mobot.org/cgi-bin/searchvast, accessed on 1 July 2011.

18. Azam F., Roy R.P., Thakur V. Cytotaxonomical studies in grasses of Bihar. Proc. $56^{\text {th }}$ Indian Sci. Congr., 1969, Part 3, pp. 353-354.

19. Mehra P.N., Khosla P.K., Kohli B.L., Koonar J.S. Cytogenetical studies in North-Indian grasses. I. Res. Bull. Punjab Univ. Sci., 1968, vol. 19, pp. 157-230.

20. Basappa G.P., Muniyamma M., Chinnappa C.C. An investigation of chromosome numbers in the genus Brachiaria (Poaceae: Paniceae) in relation to morphology and taxonomy. Canad. J. Bot., 1987, vol. 65, pp. 2297-2309.

21. Christopher J., Samraj P. In IOPB Chromosome number reports LXXXVI. Taxon, 1985, vol. 34, pp. 159-164.

22. Pohl R.W., Davidse G. Chromosome numbers of Costa Rican grasses. Brittonia, 1971, vol. 23, pp. 293-324.
23. Hsu C.C. Preliminary chromosome studies on the vascular plants of Taiwan (V). Cytotaxonomy on some Monocotyledons. Taiwania, 1972, vol. 17, pp. $48-65$.

24. Gupta B.K. In IOPB chromosome number reports XX. Taxon, 1969, vol. 18, pp. 213-221.

25. Larsen $K$. Studies in the flora of Thailand 14. Cytological studies in vascular plants of Thailand. Dansk. Bot. Ark., 1963, vol. 20(3), pp. 211-275.

26. Ahsan S.M.N., Vahidy A.A., Ali S.I. Chromosome numbers and incidence of polyploidy in Panicoideae (Poaceae) from Pakistan. Ann. Missouri Bot. Gard., 1994, vol. 81(4), pp. 775-783.

27. Mehra P.N., Chaudhary J.D. In IOPB Chromosome Number Reports XLIX. Taxon, 1975, vol. 24, pp. 501-516.

28. Mehra P.N. Cytology of East-Indian grasses. Pramodh P. Kapur at Rajbandhu Industrial Company, 1982.

29. Bir S.S., Sahni M. SOCGI plant chromosome number reports-IV. J. Cytol. Genet., 1986, vol. 21, pp. $152-154$.

30. Bir S.S., Sahni M. SOCGI plant chromosome number reports-II. J. Cytol. Genet., 1984, vol. 19, pp. 112-113.

31. Bir S.S., Gill B.S., Kanta S. In chromosome number reports LXIX. Taxon, 1980, vol. 29, pp. 703-730.

32. Bir S.S., Chauhan H.S. SOCGI plant chromosome number reports-IX. J. Cytol. Genet., 1990, vol. 25, pp. 147-148.

33. Mehra P.N., Sharma M.L. Cytological investigations on W. Himalayan Panicoideae. Cytologia, 1973, vol. 38, pp. 259-270.

34. Ismail F.A. Cytology of Andropogoneae and Paniceae. Proc. 58th Indian Sci. Congr., 1971, Part 3, pp. $463-464$.

35. Kožurov S.I., Petrova A.V. Chromosome numbers of Bulgarian Angiosperms. Fito logiya (Sofia), 1991, vol. 39, pp. 72-77.

36. Gould F.W. Chromosome numbers in southwestern grasses. Am. J. Bot., 1958, vol. 45, pp. 757-768.

37. Singh D.N., Godward M.B.E. Cytological studies in the Gramineae. Heredity, 1960, vol. 15, pp. 193-199.

38. Olorode $O$. Additional chromosome counts in $\mathrm{Ni}-$ gerian grasses. Brittonia, 1975, vol. 27, pp. 63-68.

39. Gould F.W., Ali M.A., Fairbrothers D.E. A revision of Echinochloa in United States. Am. Midl. Nat., 1972, vol. 87, pp. 35-39.

40. Davidse G., Pohl R.W. Chromosome numbers, meiotic behavior, and notes on tropical American grasses (Gramineae). Can. J. Bot., 1974, vol. 52, pp. 317-328.

41. Feng J.H., Zhang T.B. Cytological study on Chinese species in the genus Echinochloa J. Wuhan. Bot. Res., 1993, vol. 11, pp. 293-299.

ISSN 0564-3783. Цитология и генетика. 2013. № 2 
42. Hunziker J.H., Zuloaga F.O., Morrone O., Escobar A. Estudios cromosymicos en Paniceae Sudamericanas (Poaceae: Panicoideae). Darwiniana, 1998, vol. 35(1-4), pp. 29-36.

43. Church B.L. Meiotic phenomena in certain Gramineae. II. Paniceae and Andropogoneae. Bot. Gaz. (Chicago), 1929, vol. 88, pp. 63-84.

44. Malik C.P., Tripathi R.C. Species relationship in some Echinochloa strains from India. Chr. Inf. Serv., 1974, vol. 16, pp. 10-11.

45. Hunter A.W.S. A karyosystematic investigation in the Gramineae. Can. J. Res., 1934, vol. 11, pp. 213241.

46. Sahni M., Bir S.S. SOCGI Plant chromosome numberreports-III.J. Cytol. Genet., 1985, vol.20,pp. 205206.

47. Dujardin M. Additional chromosome numbers and meiotic behavior in tropical African grasses from Western Zaire. Can. J. Bot., 1979, vol. 57, pp. 864876.

48. Gill B.S., Bir S.S., Singhal V.K., Bedi Y.S. Cytological studies on some grasses from Pachmari forests (Central India). J. Cytol. Genet., 1980, vol. 15 , pp. 51-57.

49. Yang D.K. Karyotypic studies of four herbaceous species from Shandong. Guihaia, 1998, vol. 18(1), pp. 41-44.

50. Sharma A.K., Jhuri L. Chromosome analysis of grasses. I. Genet. Iber., 1959, vol. 11, pp. 145-173.

51. Mehra P.N., Chaudhary J.D. In IOPB chromosome number reports LIV. Taxon,1976, vol. 25, pp. 631649.

52. Echarte A.M., Clausen A.M., Sala C.A. Números cromosómicos y variabilidad morfolygica de Paspalum distichum (Poaceae) en la Provincia de Buenos Aires (Argentina). Darwiniana, 1992, vol. 31, pp. $185-197$.

53. Koul K.K., Gohil R.N. SOCGI plant chromosome number reports- IV. J. Cytol. Genet., 1987, vol. 22, pp. $161-162$.

54. Gohil R.N., Koul, K.K. Cytological studies on Kashmir grasses. IV. Morphological and chromosomal polymorphism in Paspalum distichum L. Nucleus (Calcutta), 1988, vol. 31, pp. 107-112.

55. Murthy T.C.S., Basavaiah Karyomorphological studies on five species of Urochloa P. Beauv. (Poaceae). Cytologia, 1990, vol. 55, pp. 431-435.

56. De Wet J.M.J. Chromosome numbers of few South African grasses. Cytologia, 1954, vol. 19, pp. 97103.
57. Moffett A.A., Hurcombe R. Chromosome numbers of South African grasses. Heredity, 1949, vol. 3, pp. 369-373.

58. Malik C.P., Mary T.N. In IOPB Chromosome number reports XXVII. Taxon, 1970, vol. 19, pp. 437442.

59. Darlington C.D., Wylie A.P. Chromosome Atlas of Flowering Plants. $2^{\text {nd }}$ ed. George Allen and Unwin, London, 1955.

60. Fedorov An.A. Chromosome numbers of flowering plants. Komarov Botanical Institute USSR, 1969, pp. 926.

61. Koul K.K., Gohil R.N. Cytogenetic studies on some Kashmir grasses. VIII Tribe Agrostideae, Festuceae and Paniceae. Cytologia, 1991, vol. 56, pp. 437452.

62. Bir S.S., Sahni M. Chromosomal and morphological variations in grasses of Punjab. J. Cytol. Genet., 1987, vol. 22, pp. 12-22.

63. Hilu K.W. Phylogenetics and chromosomal evolution in the Poaceae (grasses). Aust. J. Bot., 2004, vol. 52, pp. 13-22.

64. Smith B.W. Hybridity and apomixis in the perennial grass, Paspalum dilatatum. Genetics, 1948, vol. 33, pp. 628-629.

65. Ghaffari S.M. Occurance of diploid and polyploidy microspores in Sorghum bicolor (Poaceae) is the result of cytomixis. Afr. J. Biotechnol., 2006, vol. 5, pp. 1450-1453.

66. Kumar P., Singhal V.K., Kaur D., Kaur S. Cytomixis and associated meiotic abnormalities affecting pollen fertility in Clematis orientalis. Biol. Plantarum, 2010, vol. 54, pp. 181-184.

67. Fadaei F., Sheidai M., Asadi M. Cytological Study of genus Arenaria L. (Caryophyllaceae). Cytologia, 2010, vol. 63(2), pp. 149-156.

68. Nirmala A., Rao P.N. Genetics of chromosome numerical mosaism in higher plants. The Nucleus, 1996, vol. 39, pp. 151-175.

69. Kim J.S., Oginuma K., Tobe H. Syncyte formation in the microsporangium of Chrysanthemum (Asteraceae): a pathway to infraspecific polyploidy. J. Plant Res., 2009, vol. 122, pp. 439-444.

70. Baptista-Giacomelli F.R., Pagliarini M.S., Almeida J.L. Meiotic behavior in several Brazilian oat cultivars (Avena sativa L.). Cytologia, 2000, vol. 65, pp. 371378. 